\title{
Influence on the oxidative potential of a heavy-duty engine particle emission due to selective catalytic reduction system and biodiesel blend
}

\author{
Ricardo H.M. Godoi a,*, Gabriela Polezer ${ }^{\text {a }}$, Guilherme C. Borillo a , Andrew Brown ${ }^{\mathrm{b}}$, Fabio B. Valebona ${ }^{\mathrm{a}}$, \\ Renato A. Penteado Neto ${ }^{\text {, }}$ Mary Rosa R. de Marchi ${ }^{\text {, }}$ Paulo H.N. Saldiva ${ }^{\mathrm{g}}$, \\ Theotonio Pauliquevis ${ }^{\text {h }}$, Ana Flavia L. Godoi ${ }^{\text {a }}$ \\ a Environmental Engineering Department, Federal University of Parana, Curitiba, PR, Brazil \\ b Division of Chemistry and Environmental Science, School of Science and the Environment, Manchester Metropolitan University, Manchester, UK \\ c LAVIE - Institute of Chemistry, São Paulo State University - UNESP, Araraquara, Brazil \\ ${ }^{d}$ Chemical Engineering Department, Federal University of Parana, Curitiba, PR, Brazil \\ e Vehicle Emissions Laboratory, Institute of Technology for Development (LACTEC), Curitiba, PR, Brazil \\ ${ }^{\mathrm{f}}$ Analytical Chemistry Department, Institute of Chemistry, São Paulo State University - UNESP, Araraquara, Brazil \\ g Laboratory of Experimental Air Pollution, Department of Pathology, School of Medicine, University of São Paulo, São Paulo, Brazil \\ ${ }^{\mathrm{h}}$ Department of Natural and Earth Sciences, Federal University of São Paulo, Diadema, Brazil
} Thiago O.B. Silva ${ }^{\mathrm{a}}$, Aline B.G. Ingberman ${ }^{\mathrm{a}}$, Marcelo Nalin ${ }^{\mathrm{c}}$, Carlos I. Yamamoto ${ }^{\mathrm{d}}$, Sanja Potgieter-Vermaak ${ }^{\mathrm{b}}$,

\section{H I G H L I G H T S}

- PM emission from biodiesel burning may be more harmful to human health than diesel.

- Euro V (SCR) engine fuelled with B5 and B20 tested in a bench dynamometer

- Electron Spin Resonance (ESR) to access the oxidative potential of PM emission

- Add biodiesel in the fuel blend increases OP while SCR system reduces it.

- Free radicals generation due biodiesel can cause deleterious effects in health.

\section{A R T I C L E I N F O}

\section{Article history:}

Received 20 January 2016

Received in revised form 16 March 2016

Accepted 4 April 2016

Available online 19 April 2016

Editor: D. Barcelo

\section{Keywords:}

Oxidative potential

Diesel emission

Biodiesel emission

Particulate matter

\section{G R A P H I C A L A B S T R A C T}

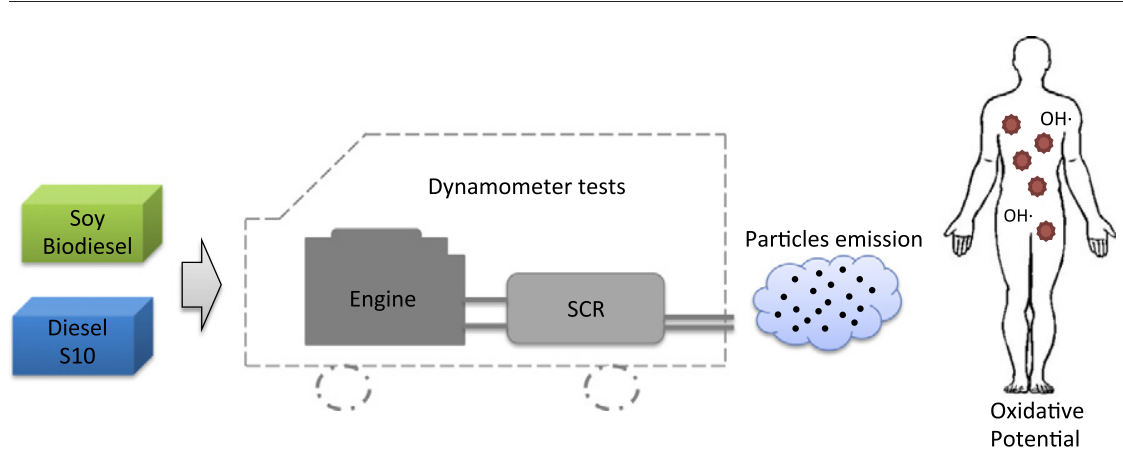

\footnotetext{
* Corresponding author at: Environmental Engineering Department, Federal University of Parana, 210 Francisco H. dos Santos St., Curitiba, PR 81531-980, Brazil. E-mail address: rhmgodoi@ufpr.br (R.H.M. Godoi).
} 
techniques used in this study highlight the link between biodiesel engine exhaust and increased oxidative potential relative to biodiesel addition on fossil diesel combustion. The EDXRF analysis confirmed the prominent role of metals on free radical production. As a whole, these results suggest that $20 \%$ of biodiesel blends run without SCR may pose an increased health risk due to an increase in $\mathrm{OH}$ radical generation.

(c) 2015 Elsevier B.V. All rights reserved.

\section{Introduction}

Particulate matter (PM) from anthropogenic sources is of particular concern to human health and has been associated with adverse health effects (Wjst et al., 1993; Kim et al., 2004; Gauderman et al., 2005; Tonne et al., 2007; Ryan et al., 2007). Such effects are linked to particles size, composition, concentration and sources (Davidson et al., 2005; Smekens et al., 2005; Viana et al., 2008; Lee and Hieu, 2011). One particularly notable source of harmful particulate emissions is diesel engines. The PM output from these engines have been linked to cardiopulmonary mortality and morbidity including cancer (Tarkiainen et al., 2003; Nemmar et al., 2007; Peretz et al., 2008; Rivero et al., 2005; Benbrahim-Tallaa et al., 2012). Despite the increase in the health risk being relatively small, the incidence of exposure is high, thus demonstrating its significant importance as the population is exposed (Lim et al., 2012). Accordingly, technologies to reduce emissions associated with diesel vehicles have been implemented (Gill et al., 2012; Borillo et al., 2015). Examples include diesel particulate filters (DPFs), aftertreatment exhaust emission systems (e.g. selective catalyst reduction - SCR). In addition, in light of renewal energy sources, biodiesel is promoted as a sustainable source (Cheng et al., 2008; Hu et al., 2009; Chin et al., 2012).

In short, biodiesel is an ester-based fuel obtained from different vegetable oils, and in some countries, has become accepted as a partial or total substitute for fossil fuels. Introduction of Diesel engines operating with biodiesel is widespread in Brazil, where the majority of this study is based. It is imperative that biofuel emissions are of a higher quality that those of traditional diesel engines for biodiesel to be a suitable alternative. Literature indicates the reduction of PM mass concentration due to use of biodiesel compared to fossil diesel (Lapuerta et al., 2008; Bünger et al., 2012; Guo et al., 2014). Similarly, SCR aftertreatment engines have been shown to reduce the quantity of PM produced and gases (Tadano et al., 2014). However, it has been suggested that despite the reduced mass concentrations of PM, cytotoxicity and pro-inflammatory marker increase with use of biodiesel relative to fossil diesel release (Kooter et al., 2011; Swanson et al., 2011; Gerlofs-Nijland et al., 2013). The effect of engine exhaust particles on oxidative potential is of particular interest for this study because of its well documented association with acute and chronic health effects (Halliwell and Gutteridge, 1999; Valko et al., 2007; Patel et al., 2011). The specific cause of excess free radical production is yet to be proved conclusively (Betha et al., 2012). One possible explanation is the increased quantity of organic matter output from biodiesel fuelled engines, oxidizing once access is gained to the body (Yanamala et al., 2013). The contribution of organic content is again estimated by Jung et al. (2006) who report increased hydroxyl radical $(\mathrm{OH} \bullet)$ production as a result of flame soot, compared to carbon black. However these concepts differ from the conventional explanation the influence of metal species. The Fenton reaction describes the production of $\mathrm{OH} \bullet$ by the reduction of hydrogen peroxide and simultaneous oxidation of transition metal ions (Shi et al., 2003). Although the example equation features oxidation of iron, this process is observed for other metals such as copper (Kadiiska and Mason, 2002), tin (Lilley et al., 2013), chromium (Lou et al., 2013), even aluminium, despite the fact it only exists in one oxidation state (Kumar and Gill, 2014).

$\mathrm{Fe}^{2+}+\mathrm{H}_{2} \mathrm{O}_{2}+\mathrm{H}^{+} \rightarrow \mathrm{Fe}^{3+}+\mathrm{H}_{2} \mathrm{O}+\mathrm{OH} \bullet$

The primary objective of this study is to assess the probable oxidative stress caused by exposure to PM of diesel and biodiesel fuelled engines using SCR aftertreatment. This was achieved by using the electron spin resonance analysis in order to measure the free radicals generation due to PM emitted by different aftertreatment/fuel settings. Raman spectroscopy and Energy Dispersive X-ray fluorescence spectroscopy (EDXRF) experimentation were carried out to provide a more in-depth understanding of the free radical chemical nature in biodiesel and diesel.

\section{Experimental section}

\subsection{PM collection}

Collection of total PM took place at Institute of Technology for Development, Lactec, Curitiba, Brazil. The engine emissions testing facilities used an engine dynamometer and an engine equipped with a urea SCR aftertreatment system, in accordance with the Euro V standard.

Table 1 shows the characteristics of the tested engine. The tested engine has an individual four-valve cylinder head, cross-flow arrangement; common rail injection system with 1800 bars and engine brake "power brake." It is used in trucks, minibuses and buses. The engine has a power output of $187 \mathrm{HP}$ (2200 rpm), a peak torque of $720 \mathrm{Nm}$ and follows the European Union regulation no. 715/2007 requirements Euro V with urea-SCR system. The European Union (EU) adopted Euro V engine since 2009 and the Euro VI engine in 2013. In Brazil, due to technological delays, especially according to high sulfur concentration in diesel fuel, the Euro V engine was established in 1 January 2012, through the PROCONVE seventh campaign. Nowadays, around 140,000 trucks and 30,000 buses equipped with SCR systems are being used in Brazil (Anfavea, 2013).

This engine works in conjunction with an AVL SESAM i60 FT dynamometer, $440 \mathrm{~kW}$ power output at 6,000 rpm and 2,334 Nm of torque. This set up uses the European Steady Cycle (ESC) test set up in accordance with the European emission regulations directive 1999/96/EC. The ESC uses different engine and dynamometer settings, designed to simulate a variety of different speeds and load weights, to allow collection of PM. The fuels used in this study were a blend of ultra-low sulfur diesel (ULSD) (10 ppm sulfur content) and soybean biodiesel in the following proportions: 5\% (B5) and 20\% biodiesel (B20). The same biodiesel were used to produce the B5 and B20 blends. The rationale behind this choice is two pronged: Firstly, to show the effect of $5 \%$ versus $20 \%$ biodiesel additions on emission profiles and secondly, both are representative of current usage all over the world. Total PM for each of these fuels was collected both with and without the SCR treatment, thus a total of four different conditions were analyzed in this study.

Table 1

Characteristics of tested engine.

\begin{tabular}{ll}
\hline Specifications & \\
\hline Configuration & Euro V ‘Heavy Duty'/proconve P7 \\
Valves/cylinder & 4 \\
Displacement & $4.8 \mathrm{~L}$ \\
Bore $\times$ stroke & $105 \times 137 \mathrm{~mm}$ \\
Combustion system & Direct injection \\
Injection system & Common rail electronic \\
Aspiration & TGV intercooler \\
Power output & $187 \mathrm{cV}(139.7 \mathrm{~kW}) 2200 \mathrm{rpm}$ \\
Peak torque & $720 \mathrm{Nm}\left(73 \mathrm{kgf} \mathrm{m}{ }^{-1}\right) 1200-1600 \mathrm{rpm}$ \\
Aftertreatment & $\mathrm{SCR}$
\end{tabular}


Table 2

Results from the fuel characterization.

\begin{tabular}{|c|c|c|c|}
\hline Parameters & B20 & B5 & Standard test methods \\
\hline Flashpoint $\left({ }^{\circ} \mathrm{C}\right)$ & 70.5 & 68.5 & ASTM D93 \\
\hline Total sulfur ( $\left.\mathrm{mg} \mathrm{kg}^{-1}\right)$ & 6 & 1 & ASTM D5453 \\
\hline Specific mass $\left(\mathrm{kg} \mathrm{m}^{-3}\right)$ & 848.1 & 841.6 & ASTM D4052 \\
\hline Colour & Yellow & Yellow & Visual \\
\hline Aspect & Clear and free from impurities & Clear and free from impurities & ABNT NBR 14954 \\
\hline Viscosity $\left(\mathrm{mm}^{2} \mathrm{~s}^{-1}\right)$ & 3.2 & 3.0 & ASTM D445 \\
\hline Cetane number & 51.0 & 53.1 & ASTM D6890 \\
\hline
\end{tabular}

The B5 and B20 fuels were previously characterized according to methods and essays described on American (ASTM) and Brazilian (NBR) standardization, results are presented on the Table 2. Total PM was collected on Teflon coated glass fiber filters (T60A20, Pallflex ${ }^{\circledR}$, Ann Arbor, MI, U.S.A.) with a constant volume sampler (smart sampler, AVL, Graz, Austria) to simulate PM dilution with air. The air dilution must be set such as the exhaust diluted gas temperature measured immediately before the first filter does not exceed $325 \mathrm{~K}\left(52^{\circ} \mathrm{C}\right)$. The dilution ratio must not be less than four. The motor data acquisition system was an Engine Computer Aided Test (E-Cat) from Sp Tronic (Guarulhos, Brazil) that can store data of temperature, pressure, rotation, torque and power simultaneously during tests execution. In order to evaluate just the effects of B5 and B20 biodiesel blends and aftertreatment system on oxidative potential, all engine tests were validated to achieve the lower variations on the other experimental parameters, according to directive 1999/96/EC of European Union. Therefore the tests with higher variations were not considered for the present study.

\subsection{Oxidative potential}

Oxidative potential (OP), as predictor for oxidative stress, was measured by Electron Spin Resonance $\left(\mathrm{OP}^{\mathrm{ESR}}\right)$ with the spin-trap 5.5-dimethyl-1-pyrroline- $N$-oxide (DMPO) in presence of hydrogen peroxide $\left(\mathrm{H}_{2} \mathrm{O}_{2}\right)$. The analyses were performed in a Miniscope MS 400 (MT MagnetTech Gmbh, Berlin, Germany).

The methodology was based on the one demonstrated by Shi et al. (2003) with adaptations regarding the exclusion of the resuspension and filtering steps, as recommended by Hellack et al. (2014). One filter per each condition $(n=1)$ and two blank filters were cut in the middle and one half inserted in a vial and $0.5 \mathrm{~mL}$ of deionized water, $1 \mathrm{~mL}$ of 0.05 M DMPO ( $\geq 98 \%$ ELSD, Enzo Life Science, Farmingdale, NY, U.S.A.) and $0.5 \mathrm{~mL}$ of $0.5 \mathrm{M} \mathrm{H}_{2} \mathrm{O}_{2}$ (p.a., Sigma-Aldrich, St. Louis, MO, U.S.A.), both prepared in a Dulbecco's chloride and calcium free phosphate Buffer (PBS) (premium, Sigma-Aldrich, St. Louis, MO, U.S.A.), were added. Vials content were mixed by vortexing (Vortex Genie-2, Scientific Industries, Bohemia, NY, U.S.A.) for $20 \mathrm{~s}$, followed by being placed in a water bath shaker (type $1092, \mathrm{GFL}$, Burgwedel, Germany) at $37{ }^{\circ} \mathrm{C}$ at $150 \mathrm{rpm}$ for $15 \mathrm{~min}$, then vortexed again for $10 \mathrm{~s}$. Finally, capillaries of $50 \mu \mathrm{L}$ (Hirschmann Laborgeraete, Eberstadt, Germany) were placed in the upper layer of the mixture and filled in order to transfer the extracts to the instrument, in which the analysis was performed. $10 \mu \mathrm{M}$ copper sulfate $\left(\mathrm{CuSO}_{4}\right)$ (p.a., Sigma-Aldrich also, St. Louis, MO, U.S.A.) in PBS was used as the positive control because of its known ability in inducing Fenton type reactions (Hellack et al., 2014). Deionized water was used as the negative control. The controls were mixed with DMPO and $\mathrm{H}_{2} \mathrm{O}_{2}$ in the same ratio as for the samples and handled as described above.

The OP ${ }^{\mathrm{ESR}}$ settings for all measurements were the following: $3390 \mathrm{G}$ magnetic field, $100 \mathrm{G}$ sweep width, 3 scans of 30 s, $2000 \mathrm{mG}$ modulation amplitude and $5 \mathrm{E} 1$ gain. The resulting $\mathrm{OP}^{\mathrm{ESR}}$ spectrum consists of four different peaks and the higher its amplitudes are, the higher is the PM elicited $\mathrm{OH}$ generation. Results are achieved by calculating the average of its total amplitudes and are expressed as arbitrary units (AU) (Hellack et al., 2014). Those were reported as emission factors in terms of the engine energy output ( $\mathrm{AU} \mathrm{kWh}{ }^{-1}$ ) in order to show the potential risk of implementing each fuel and exhaust technology.

\subsection{Bulk elemental profile}

Information concerning the bulk elemental concentration is provided by energy-dispersive X-ray fluorescence (EDXRF). The measurements of total PM were performed on a Minipal-4 (PANalytical, Almelo, The Netherlands) equipped with a Silicon Drift Detector (SDD) which is cooled thermo-electrically. For the analysis, a tube voltage of $30 \mathrm{kV}$, a current of $0.3 \mathrm{~mA}$ and an acquisition time of $600 \mathrm{~s}$ were selected, in a He-atmosphere, without any further step of sample preparation. The equipment was set to detect a comprehensive list of bulk elements: $\mathrm{Si}$, $\mathrm{S}, \mathrm{K}, \mathrm{Fe}, \mathrm{Cu}, \mathrm{Ga}, \mathrm{Mg}, \mathrm{Ca}, \mathrm{Ti}, \mathrm{Cr}, \mathrm{Mn}, \mathrm{Co}, \mathrm{Ni}, \mathrm{Zn}, \mathrm{Br}, \mathrm{Sr}, \mathrm{Ag}, \mathrm{Sn}, \mathrm{Ba}, \mathrm{Pb}$ and Se. The system calibration of the applied EDXRF method was based on thin film reference standards (Micromatter, Seattle, WA, USA) and validated by the measurement of various thin layer standards for each element and a reference material from NIST (2783 air particulate on filter media).

Metals such as $\mathrm{Fe}, \mathrm{Cr}, \mathrm{Co}, \mathrm{Mn}, \mathrm{Cu}$ and $\mathrm{Zn}$ were selected for analysis because of their ability to produce reactive oxygen species (ROS) as part of the Fenton chemistry (Rico et al., 2009; Verma et al., 2010). It was preferred to assess a broad range of elements due to the complex mechanisms that may trigger oxidative stress and the initial stage of $\mathrm{OP}^{\mathrm{ESR}}$ analysis of engine PM emissions (Shi et al., 2003; Pan et al., 2004).

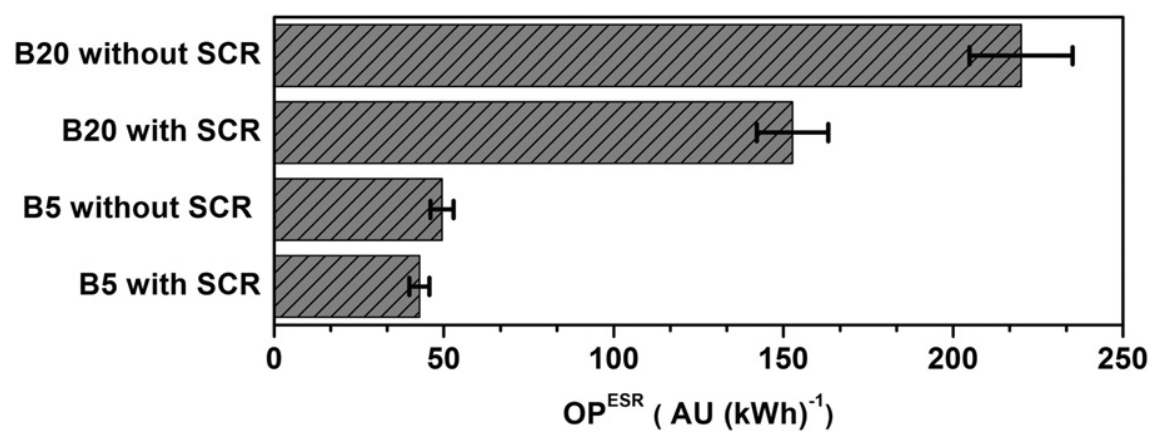

Fig. 1. $P M O P^{E S R}$ per $k W h$ and standard deviation for each operational setting of the engine. 


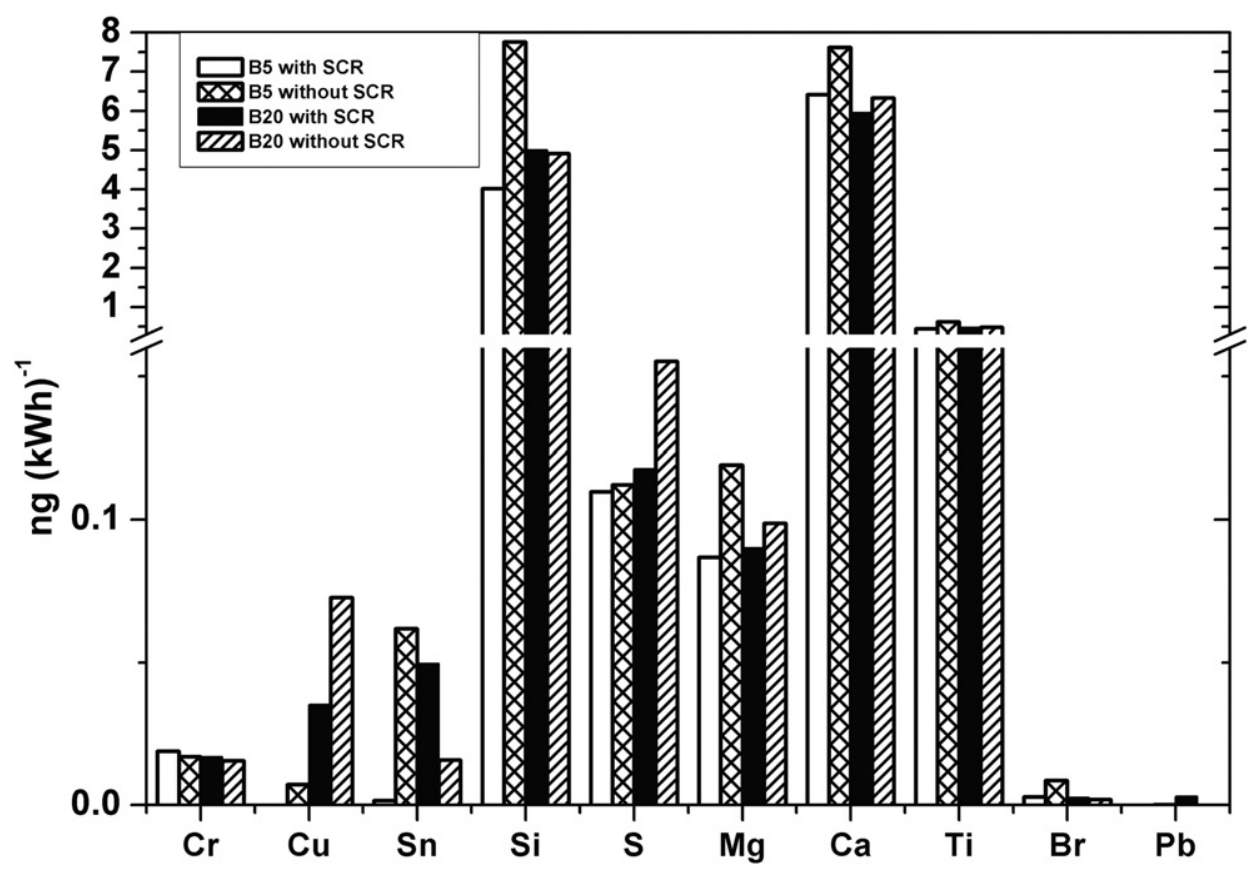

Fig. 2. Detected bulk elemental concentrations in each engine condition as determined by EDXRF.

\subsection{Raman spectroscopy}

The sampling of individual particles for analysis by Raman Spectroscopy was conducted using a May Impactor connected to the diluter, allowing control of the time and rate of air sampling. The May Impactor consists of seven sampling stages that segregate the particles by aerodynamic diameter (May, 1945). For the analysis, particles with diameter $<0.25 \mu \mathrm{m}$ were sampled, which were impacted on surface-enhanced Raman spectroscopy substrates made of a thin gold film. The SERS substrates used to collect the soot were 2D photonic crystals (PC) measuring $1 \times 1 \mathrm{~cm} \times 90 \mathrm{~nm}$ in thickness. PC was prepared using a holographic setup following the methodology developed by Menezes et al. (2006). A LabRAM Jobin-Yvon-HORIBA micro-Raman, equipped with a $632.8 \mathrm{~nm}$ He-Ne laser and $50 \times$ white light objective, was used for obtaining the Raman spectra (Soewono and Rogak, 2011). Several spots were analyzed to ensure representative results and minimize variance.

The amorphous carbon character of the soot collected can be described by their respective Raman spectra. Literature proposes 2 models to fit the rather broad Raman features, two-band and five-band model. The two-band model does not take into account the various $\mathrm{D}$ bands describing the $\mathrm{sp}^{2} / \mathrm{sp}^{3}$ character and therefore we opted for the five-band fitting proposed by Sadezky et al. (2005) (G, D1, D2, D3, and D4 at about $1580,1350,1500,1620$, and $\left.1200 \mathrm{~cm}^{-1}\right)$. The $\mathrm{G}$ band is designated to the E2g symmetry stretching mode of the $\mathrm{sp}^{2}$ graphitic lattice. The D1 band according to the classic approach is assigned to the breathing mode of $\mathrm{sp}^{2}$ atoms and is called the defect band (Ferrari, 2007). The D3 band has been assigned to defects outside the plane of aromatic layers like tetrahedral carbons, while the $\mathrm{D} 4$ bond is assigned to $\mathrm{sp}^{3}$ or $\mathrm{sp}^{2}-\mathrm{sp}^{3}$ bonded atoms and is normally only present in disordered amorphous $\mathrm{C}$. The $\mathrm{D} 2$ band's assignment is still debatable and is only present if there is disorder.

\section{Results and discussion}

\subsection{Oxidative potential}

The resulting signals were well ranged between the negative and positive controls and were normalized to give units of $\mathrm{AU} \mathrm{kWh}^{-1}$. The results are presented in Fig. 1. AU is used for Arbitrary Units. The standard deviation of positive control analyzed in five consecutive days prior and after the experiment analyses was calculated in order to check the equipment stability, resulting in a value of $6.9 \%$.

The results achieved for this study show that use of B20 increases the $\mathrm{OP}^{\mathrm{ESR}}$ of PM per kWh compared to B5 fuel. For each fuel, we can observe that the use of SCR reduces OP ${ }^{\mathrm{ESR}}$, a $30.6 \%$ and $13.5 \%$ decrease was observed for $\mathrm{B} 20$ and $\mathrm{B} 5$ respectively.

As outlined in the introduction, one of the primary motivations for this study is to assess the potential harm when using biodiesel blends and aftertreatment of the exhaust. In this study, the major impacts in $\mathrm{PM}$ emission factor variations is the use of biodiesel blend, due to its known property of reducing PM mass emission (USEPA, 2002; Xue et al., 2011; Gerlofs-Nijland et al., 2013). In order to assess the impact on human health due to different engine settings, it is relevant to evaluate the results in terms of engine operational metrics (Gerlofs-Nijland et al., 2013). This was achieved by representing the results in terms of the recommended unit in the European emission regulations directive

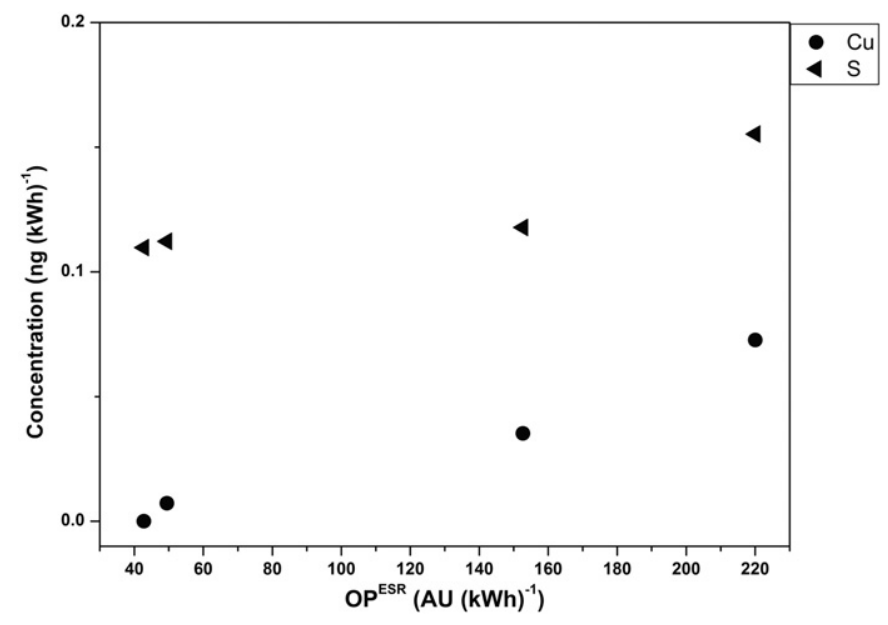

Fig. 3. Correlation between concentration of $\mathrm{Cu}$ and $\mathrm{S}$ and $\mathrm{OP} \mathrm{PSR}^{\mathrm{ES}}$. 
Table 3

Pearson correlation between concentration of metals and $\mathrm{OP}^{\mathrm{ESR}}$

\begin{tabular}{llllllllll}
\hline $\mathrm{Si}$ & $\mathrm{S}$ & $\mathrm{Cu}$ & $\mathrm{Mg}$ & $\mathrm{Ca}$ & $\mathrm{Ti}$ & $\mathrm{Cr}$ & $\mathrm{Br}$ & $\mathrm{Sn}$ & $\mathrm{Pb}$ \\
\hline-0.29 & 0.89 & 0.99 & -0.22 & -0.57 & -0.34 & -0.81 & -0.62 & -0.11 & 0.26 \\
\hline
\end{tabular}

1999/96/EC (kWh), showing that the implementation of soy biodiesel can actually enhance the $\mathrm{OP}^{\mathrm{ESR}}$ risk.

The toxicity impact of biodiesel blending and aftertreatment technologies is contrary to studies previously conducted. Kooter et al. (2011) used the dithiothreitol (DTT) catalytic reduction of oxygen to measure the OP of diesel and pure plant oil biodiesel blends PM emissions in terms of $\mathrm{kWh}$. The results showed that B0 and B20 had more or less the same OP. Gerlofs-Nijland et al. (2013) assessed the OP of diesel and rape-seed methyl-ester biodiesel blend by means of DTT and ascorbic acid consumption rate per distance driven and found that the use of B50 reduced or maintained the OP. However, when OP was analyzed in mass unit basis, some studies revealed that biodiesel can lead to PM with higher OP (Cheung et al., 2009; Gerlofs-Nijland et al., 2013). Moreover, in the majority of these studies, there was no coherence among results of different analyses of toxicity assessment (e.g.: cytotoxicity, cytokines release, oxidative stress and mutagenicity). As mentioned, the health risks are eventually determined by the amount inhaled, and OP per kWh is therefore a more useful metric to assess the health impacts.

In relation to the SCR technology, the results showed that its use reduces the $\mathrm{OP}^{\mathrm{ESR}}$ of emitted particles per kWh. Biswas et al. (2009) found a significant reduction in the OP of exhaust particles per distance driven from a heavy-duty engine when equipped with SCR technology. The authors suggest that the OP of particles is affected by catalytic surfaces and the semi volatile organics absorbed on the surface of soot particles. Moreover, among oxidant catalyzers, filter catalyzers or SCR all seems to have variables degrees of influence in changing the composition and reactivity of PM.

At the present moment, there is no single method to assess the overall OP activity of PM. Various assays to measure OP are sensitive to different groups of compounds. The DTT consumption rate is based on the ability of active reductants compound associated with PM to transfer electrons from DTT to oxygen, and are known to be sensitive to organic compounds, especially quinones emitted from diesel exhaust (Ayres et al., 2008). Ascorbic acid depletion analysis and ESR, on the other hand, are particularly sensitive to the presence of transition metals (Ayres et al., 2008; Yang et al., 2014). Furthermore, different results among several studies may be a consequence of different study configurations (Gerlofs-Nijland et al., 2013). Different factors such as, engine technology, fuel type and the use of catalyzers and filters may affect the composition and thus, the toxicity of the engine exhaust mixture, which complicates the comparison among experiments. An example would be the increased, equal or decreased toxicity potential reported from biodiesel emission studies (Bünger et al., 2000; Cheung et al., 2009; Jalava et al., 2010; Kooter et al., 2011; Swanson et al., 2011; Gerlofs-Nijland et al., 2013).

$\mathrm{OP}^{\mathrm{ESR}}$ has been suggested to be a feasible analysis for continued PM monitoring, due to its correlation with health effects, simplicity and versatility to be used with standard monitoring filters (Hellack et al., 2014). The present study showed variations among the different engine settings (SCR aftertreatment and biodiesel blends) in terms of the OP${ }^{\mathrm{ESR}}$ with the spin trap DMPO in the presence of $\mathrm{H}_{2} \mathrm{O}_{2}$. Therefore, there is a need of further investigations of the potential health effects of emissions of soy biodiesel usage. Besides this technique may be revealed as a tool for assessing PM properties beyond mass in engine testing and monitoring.

\subsection{Bulk elemental concentrations}

Among the analyzed elements only $\mathrm{Cr}, \mathrm{Cu}, \mathrm{Sn}, \mathrm{Si}, \mathrm{S}, \mathrm{Mg}, \mathrm{Ca}, \mathrm{Ti}, \mathrm{Br}$ and $\mathrm{Pb}$ presented detectable mass. Fig. 2 presents the bulk elemental concentrations as determined by EDXRF. It can be observed that there are only two samples that indicated detectable presence of lead, these low lead concentrations were expected as use of lead in fuels has been outlawed. As these values appear insignificant, the lead data will not be considered further in this discussion. Liati et al. (2013) indicate that $\mathrm{Cr}, \mathrm{Cu}, \mathrm{Si}$, Sn and Ti are common in diesel output, originating from various components of the engine, while $\mathrm{Ca}, \mathrm{Mg}$ and $\mathrm{S}$ emission are commonly related to lubricating oil additives. This appears to be consistent with the $\mathrm{Cr}$ and $\mathrm{Ti}$ data obtained from this study. EDXRF analysis indicates fairly consistent concentrations of $\mathrm{Cr}$ and $\mathrm{Ti}$ independent of fuel type or use of SCR, thus implying that the source is the engine components rather than the fuel. This is perhaps not the case with the $\mathrm{Cu}$, as a large variation in concentration can be observed between B5 and B20. The Sn, Si, Ca and Mg data appears to show no pattern and is therefore very difficult to discern the potential sources. It can be observed that there is no relationship between the concentration of these metals and the use of SCR. This is illustrated in Fig. 2. Interestingly, sources for metals in biodiesel can include leaching from storage containers. Yaakob et al. (2014) indicate that copper is particularly susceptible to this. The $\mathrm{Cu}$ results presented could indicate evidence of this.

As indicated in the previous section, $\mathrm{OP}^{\mathrm{ESR}}$ assumed the order: B20 without SCR $>$ B20 with SCR $\gg$ B5 without SCR $>$ B5 with SCR. This same pattern also existed for the concentration of copper and sulfur in each sample. Fig. 3 plots OP ${ }^{\mathrm{ESR}}$ against concentration of these elements to show correlation between its concentrations and OP. The spearman correlation between oxidative potential and bulk elemental concentrations of all detected elements is presented in Table 3. It can be observed that there is a strong correlation $(R=0.99)$ between concentration of copper and $\mathrm{OP}^{\mathrm{ESR}}$, the ability of copper to oxidize and produce radicals is documented in literature, the results in this study could be indicative of the role of copper on $\mathrm{OP}^{\mathrm{ESR}}$. Furthermore, there is evidence in literature, which suggests a link between copper and $\mathrm{OP}^{\mathrm{ESR}}$ (Shi et al., 2003; Hellack et al., 2014; Janssen et al., 2014). Another good correlation $(R=0.88)$ was obtained for sulfur. Shi et al. (2003) suggest that other inorganic components than metals, such as sulfate may affect the oxidant activity of PM. Cheng et al. (2008) found higher levels of sulfate in a biodiesel car emission than a petrodiesel one, despite the zero sulfur level in the biodiesel fuel, what was suggested to be due to lube oil sulfur. What is also interesting is the strong negative correlation present between chromium and OP ${ }^{\mathrm{ESR}}$. The pattern observed here with chromium is contrary to that observed in literature where chromium in both the common +3 and +6 oxidation states are observed to increase OP (Khan et al., 2012; Lou et al., 2013). Results for other elements, such as $\mathrm{Si}, \mathrm{Mg}, \mathrm{Ca}$, Ti and $\mathrm{Br}$ also indicated negative correlation with $\mathrm{OP}^{\mathrm{ESR}}$. However, it is important to note that a low or negative correlation with OPESR does not eliminate de potential toxicity of these elements as there are many other potential pathways of PM toxicity (Biswas et al., 2009).

Table 4

Average band positions, FWHM, and Intensity ratios of some of the Raman bands identified for the different fuels with and without SCR.

\begin{tabular}{|c|c|c|c|c|c|c|c|c|}
\hline & D1 & WD1 & $\mathrm{D} 2+\mathrm{G}$ & $W G+D 2$ & D3 & WD3 & ID3/IG + D2 & $\mathrm{ID} 1 / \mathrm{IG}+\mathrm{D} 2$ \\
\hline B20 with SCR & $1328 \pm 1$ & $192 \pm 8$ & $1600 \pm 3$ & $68 \pm 2$ & $1532 \pm 7$ & $157 \pm 10$ & $1.93 \pm 0.42$ & $4.83 \pm 0.77$ \\
\hline B20 without SCR & $1327 \pm 0.1$ & $170 \pm 3$ & $1599 \pm 1$ & $70 \pm 3$ & $1524 \pm 5$ & $163 \pm 12$ & $1.72 \pm 0.20$ & $3.72 \pm 0.50$ \\
\hline B5 with SCR & $1326 \pm 4$ & $172 \pm 14$ & $1599 \pm 3$ & $68 \pm 13$ & $1523 \pm 3$ & $174 \pm 10$ & $1.86 \pm 0.33$ & $4.20 \pm 0.58$ \\
\hline B5 without SCR & $1327 \pm 1$ & $152 \pm 12$ & $1602 \pm 1$ & $67 \pm 12$ & $1531 \pm 93$ & $139 \pm 21$ & $1.80 \pm 0.8$ & $3.83 \pm 0.49$ \\
\hline
\end{tabular}




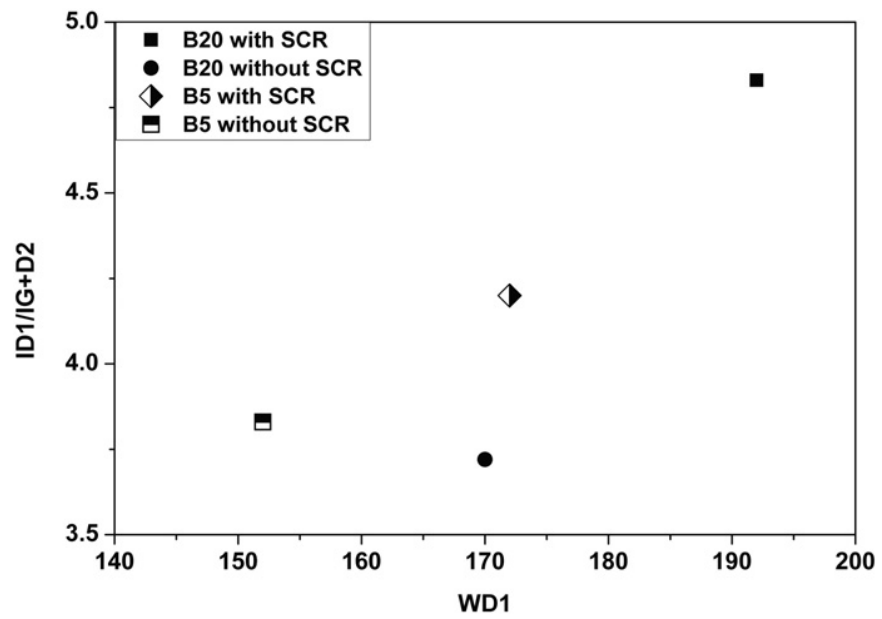

Fig. 4. The FWHM of the D1 band versus ID1/IG + D2 ratio for both fuels investigated and with and without SCR.

\subsection{Raman spectroscopy}

The deconvolution was performed by using WIRE® software. The best fit was obtained by Lorentzian-Gaussian-shaped bands for all identified bands. The D2 band could not be deconvoluted from the $\mathrm{G}$ band and the combined $\mathrm{G}+\mathrm{D} 2$ band is observed and fitted around $1600 \mathrm{~cm}^{-1}$. To avoid confusion this band will be refer to as the $\mathrm{G}+\mathrm{D} 2$ band, to indicate that we are not referring to the graphitic band on its own. In this study the band positions were assigned as follows: $\mathrm{G}+\mathrm{D} 2$ between 1597 and $1604 \mathrm{~cm}^{-1}$, D1 between 1326 and $1333 \mathrm{~cm}^{-1}$, D3 between 1520 and $1539 \mathrm{~cm}^{-1}$, and D4 between 1167 and $1196 \mathrm{~cm}^{-1}$. These values are in fair agreement with those published by Soewono and Rogak (2011). Table 4 provides some more data on the deconvoluted spectra.

Discrimination of amorphous character of the particles can be discerned from the FWHM of the D1 band. It is observed that in general the B20 had more amorphous character due to a wider D1 band, in accordance with Soewono and Rogak (2011), but in contrast to Song et al. (2006) and Lapuerta et al. (2008). It is also observed that an increase in biodiesel content suggests in increase in disorder. This has also been observed by Xu et al. (2013) and explained as the production of heavier polycyclic hydrocarbons during the pyrolysis process, which could coalesce to form amorphous structures. Furthermore, the use of the SCR seems to increase the amorphous nature of the soot as illustrated in Fig. 4. This is also in agreement with the D3/G + D2 intensity

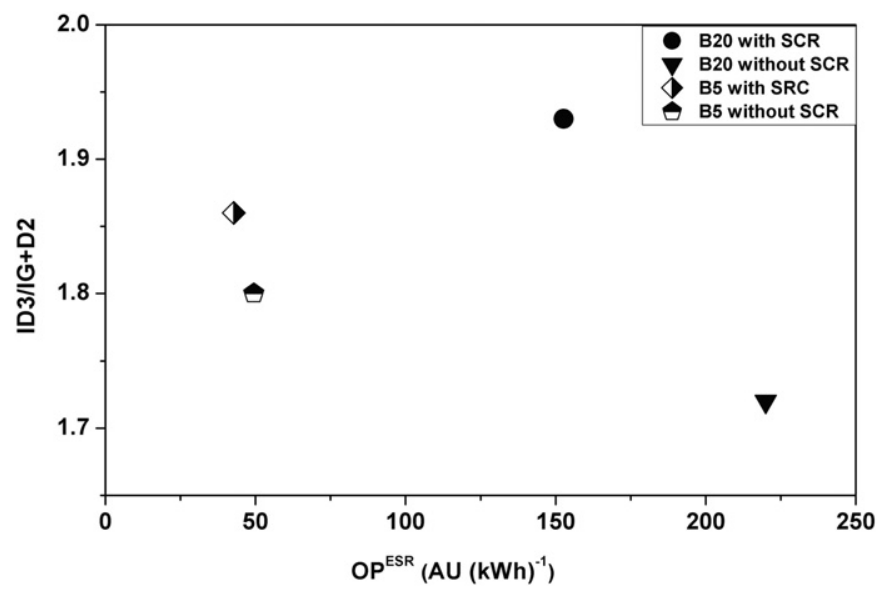

Fig. 5. The oxidation potential versus ID3/IG + D2 ratio for both fuels investigated and with and without SCR. ratios, indicating the presence of tetrahedral carbons. This contradicts the findings of Soewono and Rogak (2011), reporting ID/IG ratios of similar proportions than those reflected in Table 4 for B20 and B5 (3.2-5.2), where aftertreatment had the opposite effect.

There is an apparent inverse correlation between the OP ${ }^{\mathrm{ESR}}$ and disorder. It seems as the OP ${ }^{\mathrm{ESR}}$ increases for B20 so does the disorder decrease, which is also the case for the B5 although to a much lesser extent, as illustrated in Fig. 5.

However, overall the highest graphitic structure (B20 without SCR) showed the highest $\mathrm{OP}^{\mathrm{ESR}}$, which agrees with the study of Jung et al. (2006), outlining a ten-fold increase in $\mathrm{OH} \bullet$ production for more graphitic structures (USEPA, 2002).

\section{Conclusions}

The primary objective of this study is to assess the probable oxidative stress caused by exposure to PM of diesel and biodiesel fuelled engines using SCR aftertreatment system. This study assessed a substantial increase ( 4.5 times) in $\mathrm{OP}^{\mathrm{ESR}}$ when proportional of biodiesel is rise from $5 \%$ to $20 \%$. The use of an SCR aftertreatment system suppressed the $\mathrm{OP}^{\mathrm{ESR}}$ in all fuel evaluated.

The Raman results suggest that an increase in biodiesel content will lead to an increase in disorder of the amorphous carbons emitted when the engine is run with SCR, while the opposite is true when it is run without SCR. The highest graphitic content showed the highest $\mathrm{OP}^{\mathrm{ESR}}$, which was displayed by B20 without SCR. EDXRF data shows that concentrations of copper under each fuel condition were strongly correlated with OP. The highest $\mathrm{OP}^{\mathrm{ESR}}$ reported to the highest $\mathrm{Cu}$ concentration, which was again displayed by the B20 blend run without SCR.

These results, therefore, suggest that $20 \%$ biodiesel blends run without SCR may pose an increased health risk due to an increase in $\mathrm{OH}$ radical generation. However, these results will have to be supplemented by additional studies including 100\% of Biodiesel and pure fossil diesel to make conclusive statements in this regard.

The current results have paramount importance to inform the potential impact of Biodiesel blends on emission profiles and related health risks. This information may be of interest to the policy makers mainly for countries that already set the use of Biodiesel as USA and E.U. and for countries that have not yet adopted the use of Euro V emission standards like China, India, Australia, or Russia, as well as those already adopting it.

\section{Acknowledgement}

The authors would like to thank Dr. Cassee from Center for Environmental Health Research, National Institute for Public Health and the Environment (RIVM) by the support with $\mathrm{OP}^{\mathrm{ESR}}$ analysis. This work was supported financially by the National Council for Scientific and Technological Development (CNPq), Process Number 402391/2009-8.

\section{References}

Anfavea, 2013. National Association of Automobile Manufacturers-Brazil, Brazilian Automotive Industry Yearbook ([Http://Www.Anfavea.Com.Br/Anuario.Html, Accessed Sep 2013).

Ayres, J.G., Borm, P., Cassee, F.R., Castranova, V., Donaldson, K., Ghio, A., Harrison, R.M., Hider, R., Kelly, F., Kooter, I.M., Marano, F., Maynard, R.L., Mudway, I., Nel, A., Sioutas, C., Smith, S., Baeza-Squiban, A., Cho, A., Duggan, S., Froines, J., 2008. Evaluating the toxicity of airborne particulate matter and nanoparticles by measuring oxidative stress potential-a workshop report and consensus statement. Inhal. Toxicol. 20, 75-99.

Benbrahim-Tallaa, L., Baan, R.A., Grosse, Y., Lauby-Secretan, B., El Ghissassi, F., Bouvard, V., Guha, N., Loomis, D., Straif, K., 2012. Carcinogenic of diesel-engine and gasolineengine exhausts and some nitroarenes. Lancet Oncol. 13, 663-664.

Betha, R., Pavagadhi, S., Sethu, S., Hande, M.P., Balasubmramanian, R., 2012. Comparative in vitro cytotoxicity assessment of airborne particulate matter emitted from a stationary engine fuelled with diesel and waste cooking oil-derived biodiesel. Atmos. Environ. 61, 23-29.

Biswas, S., Verma, V., Schauer, J.J., Cassee, F.R., Cho, A.K., Sioutas, C., 2009. Oxidative potential of semi-volatile and non volatile particulate matter ( $\mathrm{pm}$ ) from heavy-duty vehicles retrofitted with emission control technologies. Sci. Total Environ. 43, 3905-3912. 
Borillo, G.C., Tadano, Y.S., Godoi, A.F.L., Santana, S.S.M., Weronka, F.M., Penteado Neto, R.A Rempel, D., Yamamoto, C.I., Potgieter-Vermaak, S., Potgieter, J.H., Godoi, R.H.M., 2015. Effectiveness of selective catalytic reduction systems on reducing. Sci. Total Environ. 49, 3246-3251.

Bünger, J., Krahl, J., Baum, K., Schröder, O., Müller, M., Westphal, G., Ruhnau, P., Schulz, T.G., Hallier, E., 2000. Cytotoxic and mutagenic effects, particle size and concentration analysis of diesel engine emissions using biodiesel and petrol diesel as fuel. Arch. Toxicol. 74 (8), 490-498.

Bünger, J., Krahl, J., Schroder, O., Schmidt, L., Westphal, G.A., 2012. Potential hazards associated with combustion of bio-derived versus petroleum-derived diesel fuel. Crit. Rev. Toxicol. 42, 732-750.

Cheng, C.H., Cheung, C.S., Chan, T.L., Lee, S.C., Yao, C.D., Tsang, K.S., 2008. Comparison of emissions of a direct injection diesel engine operating on biodiesel with emulsified and fumigated methanol. Fuel 87, 1870-1879.

Cheung, K.L., Polidori, A., Ntziachristos, L., Tzamkiozis, T., Samaras, Z., Cassee, F.R., Gerlofs, K, Sioutas, C., 2009. Chemical characteristics and oxidative potential of particulate matte emissions from gasoline, diesel, and biodiesel cars. Sci. Total Environ. 43, 6334-6340.

Chin, J., Batterman, S.A., Northrop, W.F., Bohac, S.V., Assanis, D.N., 2012. Gaseous and particulate emissions from diesel engines at idle and under load: comparison of biodiese blend and ultralow sulphur diesel fuels. Energy Fuel 26, 6737-6748.

Davidson, C.I., Phalen, R.F., Solomon, P.A., 2005. Airborne particulate matter and human health: a review. Aerosol Sci. Technol. 39, 737-749.

Ferrari, A., 2007. Raman spectroscopy of graphene and graphite: disorder, electronphonon coupling, doping and nonadiabatic effects. Solid State Commun. 143, 47-57.

Gauderman, W.J., Avol, E., Lurmann, F., Kuenzli, N., Gilliland, F., Peters, J., McConnell, R. 2005. Childhood asthma and exposure to traffic and nitrogen dioxide. Epidemiology 16, 737-743.

Gerlofs-Nijland, M.E., Totlandsdal, A.I., Tzamkiozis, T., Leseman, D.L., Samaras, Z., Låg, M., Schwarze, P., Ntziachristos, L., Cassee, F.R., 2013. Cell toxicity and oxidative potential of engine exhaust particles: impact of using particulate filter or biodiesel fuel blend. Sci. Total Environ. 47, 5931-5938.

Gill, S.S., Turner, D., Tsolakis, A., York, A.P.E., 2012. Controlling soot formation with filtered EGR for diesel and biodiesel fuelled engines. Sci. Total Environ. 46, 4215-4222.

Guo, J., Ge, Y., Hao, L., Tan, J., Li, J., Feng, X., 2014. On-road measurements of regulated pollutants from diesel and cng buses with urea selective catalytic reduction system. Atmos. Environ. 99, 1-9.

Halliwell, B., Gutteridge, J.M.C., 1999. Free Radicals in Biology and Medicine. Oxford University Press.

Hellack, B., Yang, A., Cassee, F.R., Janssen, N.A., Schins, R.P., Kuhlbusch, T.A., 2014. Intrinsic hydroxyl radical generation measurements directly from sampled filters as a metric for the oxidative potential of ambient particulate matter. J. Aerosol Sci. 72, 47-55.

Hu, Y., Griffiths, K., Norton, P.R., 2009. Surface science studies of selective catalytic reduction of no: progress in the last ten years. Surf. Sci. 603, 1740-1750.

Jalava, P.I., Tapanainen, M., Kuuspalo, K., Markkanen, A., Hakulinen, P., Happo, M.S. Pennanen, A.S., Ihalainen, M., Yli-Pirilä, P., Makkonen, U., Teinilä, K., MäkiPaakkanen, J., Salonen, R.O., Jokiniemi, J., Hirvonen, M.R., 2010. Toxicological effects of emission particles from fossil-and biodiesel-fueled diesel engine with and without doc/poc catalytic converter. Inhal. Toxicol. 22, 48-58.

Janssen, N.A.H., Yang, A., Strak, M., Steenhof, M., Hellack, B., Gerlofs-Nijland, M.E. Kuhlbusch, T., Kelly, F., Harrison, R., Brunekreef, B., Hoek, G., Cassee, F., 2014. Oxidative potential of particulate matter collected at sites with different source characteristics. Sci. Total Environ. 472, 572-581.

Jung, H., Guo, B., Anastasio, C., Kennedy, I.M., 2006. Quantitative measurements of the generation of hydroxyl radicals by soot particles in a surrogated lung fluid. Atmos. Environ. 40, 1043-1052.

Kadiiska, M.B., Mason, R.P., 2002. In vivo copper-mediated free radical production: an esr spin-trapping study. Spectrochim. Acta Part A 58, 1227-1239.

Khan, F.H., Ambreen, K., Fatima, G., Kumar, S., 2012. Assessment of health risks with reference to oxidative stress and DNA damage in chromium exposed population. Sci. Total Environ. 430, 68-74.

Kim, J.J., Smorodinsky, S., Lipsett, M., Singer, B.C., Hodgson, A.T., Ostro, B., 2004. Trafficrelated air pollution near busy roads - the east bay children's respiratory health study. Am. J. Respir. Crit. Care Med. 170, 520-526.

Kooter, I.M., Van Vugt, M.A.T.M., Jedynska, G., Tromp, P.C., Houtzager, M.M.G., Verbeek, R.P., Kadijk, G., Mulderij, M., Krul, C.A.M., 2011. Toxicological characterisation of diesel engine emissions using biodiesel and closed soot filter. Atmos. Environ. 45, 1574-1580.

Kumar, V., Gill, K.D., 2014. Oxidative stress and mitochondrial dysfunction in aluminium neurotoxicity and its amelioration: a review. Neurotoxicology 41, 154-166.

Lapuerta, M., Rodriguez-Fernandez, J., Agudelo, J.R., 2008. Diesel particulate emissions from used cooking oil. Bioresour. Technol. 99, 731-740.

Lee, B.K., Hieu, N.T., 2011. Seasonal variation and sources of heavy metals in atmospheric aerosols in a residential area of Ulsan, Korea. Aerosol Air Qual. Res. 11, 679-688.

Liati, A., Schriedber, D., Eggenschwiler, P.D., Dasilva, Y.A.R., 2013. Metal particle emission in the exhaust stream of diesel engines: and electron microscope study. Sci. Total Environ. 47, 14495-14501.

Lilley, T.M., Ruokolainen, L., Meierjohann, A., Kanerva, M., Stauffer, J., Laine, V.N., Atosuo, J., Lilius, E.M., Nikinmaa, M., 2013. Resistance to oxidative damage but not immunosuppression by organic tin compounds in natural populations of Daubenton's bats (Myotis daubentonii). Comp. Biochem. Physiol. Part C: Toxicol. Pharmacol. 157, 298-305.

Lim, S.S., Vos, T., Flaxman, A.D., et al., 2012. A comparative risk assessment of burden of disease and injury attributable to 67 risk factors and risk factor in 21 regions, 1990-2010: a systematic analysis for the global burden of disease study 2010. Lancet $380,2224-2260$

Lou, J., Jin, L., Wu, N., Tan, Y., Song, Y., Gao, M., Liu, K., Zhang, X., He, J., 2013. DNA damage and oxidative stress in human b lymphoblastoid cells after combined exposure to hexavalent chromium and nickel compounds. Food Chem. Toxicol. 55, 533-540.
May, K.R., 1945. The cascade impactor: an instrument for sampling coarse aerosols. J. Sci. Instrum. 22 (10), 187.

Menezes, J.W., Cescato, L., Carvalho, E.J., Braga, E.S., 2006. Recording different geometries of 2D hexagonal photonic crystals by choosing the phase between two-beam interference exposures. Opt. Express 14 (19), 8578-8583.

Nemmar, A., Al-Maskari, S., Ali, B.H., Al-Amri, I.S., 2007. Cardiovascular and lung inflammatory effects induced by systemically administered diesel exhaust particles in rats. Am. J. Physiol. Lung Cell. Mol. Physiol. 292, 1664-1670.

Pan, C.J.G., Schmitz, D.A., Cho, A.K., Froines, J., Fukuto, J.M., 2004. Inherent redox properties of diesel exhaust particles: catalysis of the generation of reactive oxygen species by biological reductants. Toxicol. Sci. 81 (1), 225-232.

Patel, H., Eo, S., Kwon, S., 2011. Effects of diesel particulate matter on inflammatory responses in static and dynamic culture of human alveolar epithelial cells. Toxicol. Lett. 200, 124-131.

Peretz, A., Kaufman, J.D., Trenga, C.A., Allen, J., Carlsten, C., Aulet, M.R., Adar, S.D., Sullivan, J.H., 2008. Effects of diesel exhaust inhalation on heart hate variability in human volunteers. Environ. Res. 107, 178-184.

Rico, D., Martin-Gonzalez, M., Diaz, S., De Lucas, D., Gutierrez, J., 2009. Heavy metals generate reactive oxygen species in terrestrial and aquatic ciliated protozoa. Comp. Biochem. Physiol. Part C: Toxicol. Pharmacol. 149, 90-96.

Rivero, D.H., Soares, S.R., Lorenzi-Filho, G., Saiki, M., Godleski, J.J., Antonangelo, L., Dolhnikoff, M., Saldiva, P.H., 2005. Acute cardiopulmonary alterations induced by fine particulate matter of Sao Paulo, Brazil. Toxicol. Sci. 85, 898-905.

Ryan, P.H., Lemasters, G.K., Biswas, P., Levin, L., Hu, S., Lindsey, M., Bernstein, D.I., Lockey, J., Villareal, M., Khurana, Hershey, G.K., Grinshpun, S.A., 2007. A comparison of proximity and land use regression traffic exposure models and wheezing in infants. Environ. Health Perspect. 115, 278-284

Sadezky, A., Muckenhuber, H., Grothe, H., Niessner, R., Pöschl, U., 2005. Raman microspectroscopy of soot and related carbonaceous materials: spectral analysis and structural information. Carbon 43, 1731-1742.

Shi, T., Schins, R.P., Knaapen, A.M., Kuhlbusch, T., Pitz, M., Heinrich, J., Borm, P.J., 2003. Hydroxyl radical generation by electron paramagnetic resonance as a new method to monitor ambient particulate matter composition. J. Environ. Monit. 5, 550-556.

Smekens, A.; Godoi, R.M.H.; Berghmans, P.; Van Grieken, R., 2005. Characterisation of soot emitted by domestic heating, aircraft and cars using diesel or biodiesel. J. Atmos. Chem., Volume 52, Issue 1, pp 45-62.

Soewono, A., Rogak, S., 2011. Morphology and raman spectra of engine-emitted particulates. Aerosol Sci. Technol. 45.

Song, J., Alam, M., Boehman, A.L., Kim, U., 2006. Examination of the oxidation behaviour of biodiesel soot. Combust. Flame 146, 589-604.

Swanson, K.J., Kado, N.Y., Funk, W.E., Pleil, J.D., Madden, M.C., Ghio, A.J., 2011. Release of the pro-inflammatory markers by beas-2b cells following in vitro exposure to biodiesel extracts. Open Toxicol. J. 3, 8-15.

Tadano, Y.S., Borillo, G.C., Godoi, A.F.L., Cichon, A., Silva, T.O.B., Valebona, F.B., Errera, M.R., Penteado Neto, R.A., Rempel, D., Martin, L., Yamamoto, C.I., Godoi, R.H.M., 2014. Gaseous emissions from a heavy-duty engine equipped with SCR after treatment system and fuelled with diesel and biodiesel: assessment of pollutant dispersion and health risk. Sci. Total Environ. 500-501, 64-71.

Tarkiainen, T.H., Timonen, K.L., Vanninen, E.J., Alm, S., Hartikainen, J.E., Pekkanen, J., 2003. Effect of acute carbon monoxide exposure on heart rate variability in patients with coronary artery disease. Clin. Physiol. Funct. Imaging 23, 98-102.

Tonne, C., Melly, S., Mittleman, M., Coull, B., Goldberg, R., Schwartz, J., 2007. A case-control analysis of exposure to traffic and acute myocardial infarction. Environ. Health Perspect. 115, 53-57.

USEPA, 2002. Comprehensive analysis of biodiesel impacts on exhaust emissions. Draft Technical Report, Epa420-02-001.

Valko, M., Leibfritz, D., Moncol, J., Cornin, M.T.D., Mazur, M., Telser, J., 2007. Free radicals and antioxidants in normal physiological functions and human disease. Int. J. Biochem. Cell Biol. 39, 44-84.

Verma, V., Shafer, M.M., Schaur, J.J., Sioutas, C., 2010. Contribution of transition metals in the reactive oxygen species activity of pm emissions from retro-fitted heavy duty vehicles. Atmos. Environ. 44, 5165-5173.

Viana, M., Kuhlbusch, T.A.J., Querol, X., Alastuey, A., Harrison, R.M., Hopke, P.K., Winiwarter, W., Vallius, M., Szidat, S., Prévôt, A.S.H., Hueglin, C., Bloemen, H., Wåhlin, P., Vecchi, R., Miranda, A.I., Kasper-Giebl, A., Maenhaut, W., Hitzenberger, R., 2008. Source apportionment of particulate matter in europe: a review of methods and results. J. Aerosol Sci. 39, 827-849.

Wjst, M., Reitmeir, P., Dold, S., Wulff, A., Nicolai, T., von Loeffelholz-Colberg, E.F., von Mutius, E., 1993. Road traffic and adverse-effects on respiratory health in children. Br. Med. J. 307, 596-600.

Xu, Z., Li, X., Guan, C., Huang, Z., 2013. Characteristics of exhaust diesel particles from different oxygenated fuels. Fuel 27, 7579-7586.

Xue, J., Grift, T.E., Hansen, A.C., 2011. Effect of biodiesel on engine performances and emissions. Renew. Sust. Energ. Rev. 1098-1116.

Yaakob, Z., Narayanan, B.N., Padikkaparambil, S., Unni, S., Akbar, P.M., 2014. A review of the oxidation stability of biodiesel. Renew. Sust. Energ. Rev. 35, 136-153.

Yanamala, N., Hatfield, M.K., Farcas, M.T., Schwegler-Berry, D., Hummer, J.A., Shurin, M.R., Birch, M.E. Gutkin, D.W., Kisin, E. Kagan, V.E., Bugarski, A.D., Shvedova, A.A., 2013. Biodiesel versus diesel exposure: enhanced pulmonary inflammation, oxidative stress, and differential morphological changes in the mouse lung. Toxicol. Appl. Pharmacol. 272, 373-383.

Yang, A., Jedynska, A., Hellack, B., Kooter, I., Hoek, G., Brunekreef, B., Kuhlbusch, T.A.J., Cassee, F.R., Janssen, N.A., 2014. Measurement of the oxidative potential of $\mathrm{pm}_{2.5}$ and its constituents: the effect of extraction solvent and filter type. Atmos. Environ. 83, 35-42. 